\title{
ORGANIC AGRICULTURAL PRODUCTION IN THE FUNCTION OF REDUCING RURAL POVERTY - THE EXAMPLE OF VELEBIT VILLAGE IN THE A.P. OF VOJVODINA
}

\author{
Ljubica Komazec* and Marko Aleksic \\ Faculty of Economics in Subotica - University of Novi Sad, Subotica, The Republic of Serbia
}

\begin{abstract}
Disturbing media pictures of the deterioration and disappearance of villages in almost all parts of the Republic of Serbia (RS), as a consequence of insufficient progress in the implementation of the paradigm of the rural way of life, desirable and necessary for any community and any economy, are an alarming call to every subject of the society to do whatever they are entitled to and capable of to stop these unfavorable processes. The potentials of a small rural community in RS to survive and develop for its own benefit and for the benefit of the society as a whole have studied in this article. Bearing in mind the fact that relevant social documents have their significance and role in all social processes, but are not a sufficient precondition for their improvement, the authors surveyed and interviewed the local population in the Velebit village about their attitudes, potentials, needs and limitations regarding the establishment of and their permanent involvement in organic agricultural production necessary for the village to survive and improve its economic and social position. The research results show that the inhabitants of the village of Velebit are interested in remaining in the countryside and setting up organic agricultural production, but they need assistance, both advisory and financial, as they lack sufficient capacities for it.
\end{abstract}

Keywords: organic production, poverty rate, rural environments, sustainable development

JEL Classification: Q01, Q18, Q58

\section{INTRODUCTION}

It has been 15 years since the definition and the design of the humane and universal idea of permanent and just world peace, in compliance with the goals

\footnotetext{
* Correspondence to: Lj. Komazec, Faculty of Economics in Subotica, University of Novi Sad, Segedinski put 9-11, 24000 Subotica, The Republic of Serbia; e-mail: ljkomazec@ef.uns.ac.rs
}

and principles of the Millennium Declaration of the United Nations, signed by all the member countries of the United Nations in September 2000. The global consensus on sustainable development and survival on Planet Earth is inconceivable without fairness and a reduction in the contradictions of the contemporary world in terms of the quality of life, as well as international and intergenerational solidarity (Pečujlić, 2002; Mander, Goldsmith, 2003; Gidens 2005). The Millennium Declaration has traced 
international relations in the 21st century along the principles of freedom, equality, solidarity, tolerance, respect for nature and the allocation of responsibility, suggesting that developing countries (where poverty and exclusion, and other problems related to these, are especially made manifest) should define their own national development strategies with the measures and alternatives they would achieve the millennium development goals with (Komazec, 2009; Komazec, 2011).

The Government of the Republic of Serbia included the Millennium Development Goals in the Poverty Reduction Strategy (Vlada Republike Srbije, 2003), and in 2005, witnessed the evaluation of trends and progress in achieving each millennium goal. Two national reports on social inclusion and poverty reduction in the Republic of Serbia have been presented so far - one in 2011 (for the period 20082010) and the other in 2014 (for the period 2011-2014). Singling out the importance of reaching the European social model with the objective to approach Eurointegrations (Radić, 2007), the Republic of Serbia, its bodies and institutions have made significant steps in the processes of developing relevant policies, the institutional and regulatory bodies defined by the strategic framework of the European Union, known as Europe 2020: The strategy of smart, sustainable and inclusive growth.

The above-mentioned strategy focuses on 11 areas important for a more successful coordination of economic and social policies, including rural development (Bogdanov, 2007). The strategy in this area is aimed at helping farmers to increase their competitiveness and promote the development of rural areas, especially in less attractive regions. In compliance with these goals, the financing of farmers is oriented to the protection of the environment and the quality of products. Establishing the European Agricultural Fund for Rural Development is the confirmation of seriousness and devotion to the defined idea (Ristic, 2013).

Starting from the strategic national orientation to poverty reduction in RS, particularly rural poverty, and factually highly unfavorable conditions in this area, the authors decided to take as their research topic the vicious circle of rural poverty as a consequence of the demographic depletion of the countryside, its age, as well as the overall economic deterioration.

The objective of the study is to prove that these negative processes can be stopped by having all stakeholders, both members of this small rural community and the company as a whole, appropriately engaged.

As regards the research subject and the objective, the paper starts from the following hypotheses:

H1: The members of the small rural community of the village of Velebit in the Autonomus Province of Vojvodina are interested in staying and living in their village, and improving the quality of life in it.

H2: The inhabitants of this village have certain knowledge and awareness of resolving the problem of the survival of the village, but lack sufficient capacities to resolve them by themselves.

The research process used the methods of direct field surveys and the interviewing of the inhabitants of the chosen village, and the corresponding mathematical and statistical methods of processing and presenting the obtained data.

\section{THE EXTENTS OF THE POVERTY REDUCTION STRATEGY IN RS - THE INSTITUTIONAL (IN)CAPACITY}

The Government of Serbia's Poverty Reduction Strategy (Vlada Republike Srbije, 2003) has devised three main directions, i.e. the objectives, including a struggle against poverty and the improvement of the welfare system of protecting the most endangered social groups, highlighting that poverty in RS is more complex and specific not only compared to poverty in developed countries (Ministarstvo za nauku i tehnološki razvoj, 2009), but also to poverty in transition countries, as a consequence of the extremely complex and dramatic political and economic processes undergone by the Serbian society in a relatively short time period (the wars, the sanctions, the inflation, the 
NATO aggression, the property transformation, the structural economic adjustments etc.). These processes have resulted in the occurrence of widely-present poverty in all social groups and social strata.

Based on the research aimed at shaping and adopting a poverty reduction strategy, the following categories of the Serbian population have been identified as the most exposed to the risk of poverty: (Vlada Republike Srbije, 2003): uneducated population; unemployed persons and their dependents; old persons (65+) and children; households with five and more members; elderly single- or two-person households, especially in rural communities; inhabitants of the rural areas of south-eastern and western RS; the Roma, internally displaced persons and invalids.

It is easy to notice the overlapping between all the above categories and the rural population.

The rural aspects of poverty gain significance if one takes into account the factors-trends in dominant demographic and economic processes on Serbia's territory, resulting in rural poverty (Vlada Republike Srbije, 2003): the demographic depletion of rural areas, intra-regional demographic differentiations, and the atomization of communities in underdeveloped rural areas.

Taking into account the indisputable significance of social documents (such as strategies, action plans and reports) in the processes of resolving social problems, the research in this article focused on the two important pivotal points: the Second National Report on Social Inclusion and Poverty Reduction in the Republic of Serbia (Vlada Republike Srbije, 2014) and the project entitled "Social Laboratory the Municipality of Kanjiža" (Komazec, Marjanov, Panjević, 2011).

The research motives were initiated by the conclusions and the proposed measures of the Second National Report on Social Inclusion and Poverty Reduction, especially (Vlada Republike Srbije, 2014):

- Demographic erosion is one of the key features of rural areas. The average population density in rural areas is 50 inhabitants per $\mathrm{km} 2$. The ratio of the rural population in the total population is
$40.56 \%$, and the average age in rural areas is 43.6 . The ageing index in 2010 was 130 compared to 94 in cities, and $82.5 \%$ of communities had negative population growth. A total of 986 communities have fewer than 100 members, whereas no children were born in 1,485 communities (31\%), and 31.8\% of the total live born and as much as $47.38 \%$ of the deceased were from rural areas.

- If the level of absolute poverty in the period 2011-2013 is viewed, the percentage of the poor population is twice as high in rural areas compared to urban ones. In 2013, $12 \%$ of the population of rural areas was absolutely poor compared to $6.3 \%$ in urban areas. One-to-five-hectare farms responded more negatively to the economic crisis. According to the Agricultural Census in 2012, more than $76 \%$ of the farms belong to the category possessing less than 5 hectares, and they only account for $30 \%$ of the areas. The largest number of family households in Serbia use up to two hectares of agricultural land $(48.2 \%$ of the total number), and these households farm more than $9 \%$ of agricultural land. In Europe, almost 70\% of farms have less than five hectares of farming land.

- Compared to the urban population, the population in rural communities shows higher rates of activity and employment, and lower rates of unemployment and inactivity (Reinert, 2004). The unemployment rate of the rural population (aged 15 to 64) in 2011 amounted to 21.9\% only to have shown a fall in 2013, when it amounted to $19.9 \%$. The employment rate over the same period grew by 2.8 percent, from 47.4 to $50.2 \%$. The number of self-employed persons in rural areas grew by 3.5 percent in the period 2011-2013, and was twice as high as in urban areas, whereas the number of helping household members reached about $16 \%$ in the observed period. Almost all informal employment was in the agriculture, the construction, and the services and accommodation sectors, while agriculture in rural areas contributed with $64.4 \%$. According to the most frequent status on the labor market among the self-employed, including farmers, the poverty risk rate was higher, and amounted to $38.3 \%$. 
The second motive, more important for the researchers, is to try themselves, directly in field conditions, in a small rural community, to establish the causes of the lag in development, potentials for exiting the poverty zone, the population's attitudes and their perception of the rural environment, and a possibility of using the opportunities they have, with the help of relevant institutions. The selected community was the village of Velebit, located in the A. P. of Vojvodina (Aleksić, 2013).

\section{ABOUT THE VILLAGE OF VELEBIT IN THE A.P. OF VOJVODINA}

The village of Velebit belongs to the municipality of Kanjiža and is situated between Lake Palić and Kanjiža Spa, at the altitude of 106 meters. The village is recognized as a high-quality air spa and is known for its high-quality soil suitable for organic farming.

The survey covered 28 households, with the following age and education structure, shown in Table 1.

Table 1 The age structure and the education level of the surveyed household members

\begin{tabular}{|c|c|c|c|c|c|c|c|c|c|c|}
\hline \multirow{2}{*}{$\begin{array}{l}\text { Age } \\
\text { Sex }\end{array}$} & \multicolumn{2}{|c|}{ Up to 14} & \multicolumn{2}{|c|}{$15-24$} & \multicolumn{2}{|c|}{$25-49$} & \multicolumn{2}{|c|}{$50-64$} & \multicolumn{2}{|c|}{$65^{+}$} \\
\hline & M & $\mathrm{F}$ & M & $\mathrm{F}$ & M & $\mathrm{F}$ & M & $\mathrm{F}$ & M & $\mathrm{F}$ \\
\hline No school & 4 & & & & & & & & & \\
\hline Elementary school & 1 & 1 & & & 2 & 1 & 2 & 2 & 1 & 2 \\
\hline $\begin{array}{l}\text { 3-year secondary } \\
\text { school }\end{array}$ & & & 2 & 1 & 3 & 2 & 9 & 5 & 1 & \\
\hline $\begin{array}{l}\text { 4-year secondary } \\
\text { school }\end{array}$ & & & 6 & 2 & 7 & 5 & 7 & 5 & & 1 \\
\hline Higher education & & & & 1 & 4 & 7 & 1 & 1 & & \\
\hline
\end{tabular}

Source: Authors

The Table 1 shows that the majority of the population comprises people between 25 and 64 years of age, with the majority of the female population aging from 25 to 49 , whereas the majority of the male population is over 50. As for the education levels, most of the female population finished tertiary education, whereas the male population mostly finished three- or fouryear secondary school. The number of children and elementary school students is extremely low, as seen from the fact that only six of them attend the elementary school in the village.

The surveyed participants assessed the quality of life in the countryside as follows - in Figure 1.

Although the minority of the respondents (46.43\%) assessed the life in the countryside as good or very good, most of them would not leave the village.

Based on Figure 2, it is obvious that the majority of the inhabitants would never move away. The problem the village is faced with is that there are a large number of abandoned houses, whose owners live away from the village, come to the village weekly, monthly or almost not at all, so the houses are in a state of disrepair and are gradually dilapidating. Although the houses are relatively cheap, there are almost no new inhabitants. Most villagers move to cities primarily looking for work and in order to ensure further education for their children. As it can be concluded from the above, the trend of abandoning villages in RS and leaving for larger towns has not spared this village, either, so that it is gradually ageing. The average age of the population in this village has increased, having amounted to

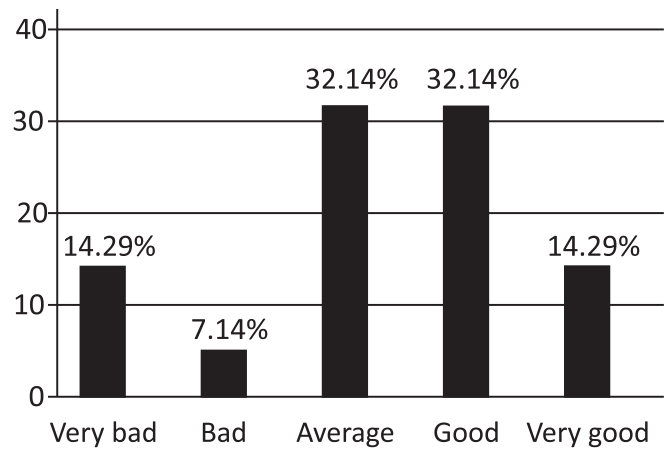

Figure 1 How do you evaluate the quality of life in the countryside?

Source: Authors 


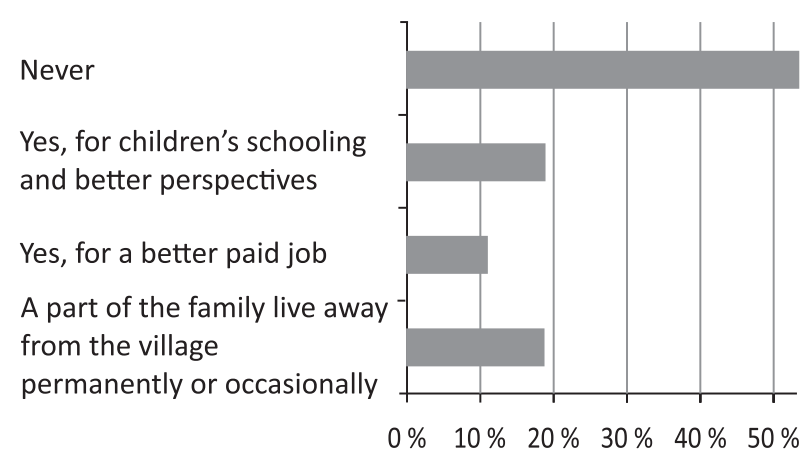

Figure 2 Would you move away from your village?

Source: Authors

50 years. The young people in the village have been declining in number, so there are fewer and fewer children in the village school and the kindergarten.

When asked what would help them to live better, the respondents answered as follows - in Figure 3.

According to the Figure 3, it can be concluded that the villagers need a better-organized market, so as to provide more sources of income and that they see their future in agriculture. Access to loans is necessary for the households that see their future in launching their private businesses or on farms. The households that plan to launch their own businesses outside agriculture also state that they need better access to information as

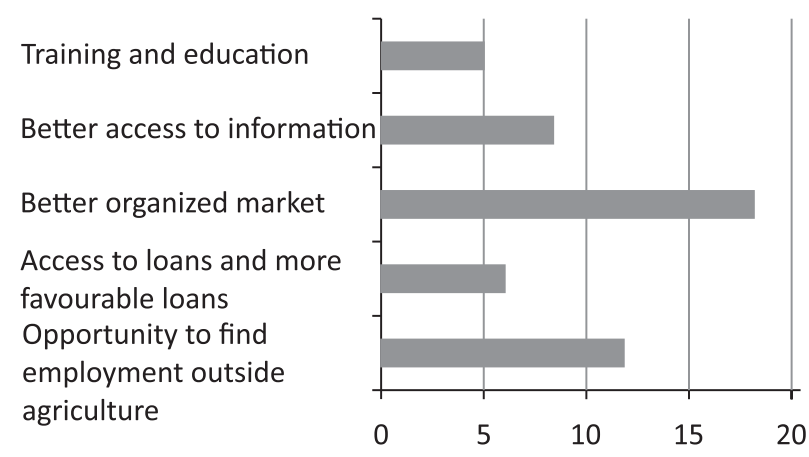

Figure 3 What would help you live better?

Source: Authors a help for improving the current situation (Bogdanov, 2007). However, they point out a greater role of the state and its incentive measures as the main prerequisite for improving agricultural production.

\section{ORGANIC AGRICULTURAL PRODUCTION IN THE VILLAGE OF VELEBIT - PROSPECTS AND OPPORTUNITIES}

Organic production preserves the health of people and the environment as well as the entire agro-eco system. Production is based on the rational utilization of resources, the use of as many renewable resources as possible, and environmental protection. This system excludes the use of any synthesized substances (Serbia organica, 2013).

Organic production has the following characteristics: it is based on natural processes and the use of organic and natural mineral substances; the use of substances of a synthetic and chemical origin is excluded, except for the cases regulated by the law; genetically modified organisms and their derivatives cannot be used; reproduction materials (seeds, seedlings, young animals and eggs) used in organic production must be produced organically; organic agriculture is a system of ecological production management, enhancing biodiversity, the circulation of substances in nature, the biological activity of the soil, and environmental protection; the spatial isolation of plots, cattle farms and processing facilities from possible sources of pollution; unpolluted soil, where the harmful substance content is below the maximum allowed limits; the inclusion of a land plot in organic production can start immediately if the plot has been not used in the past two or three years for growing long-term crops, or has been used without synthetic chemical substances; if it has, the conversion period is two or three years; organic production can be based on production units including pastures or another land where fodder is produced or a land where certified food is produced (Božić, Bogdanov, Ševarlić, 2011); the inclusion of cattle farming into organic production can start at least a year from the day of the inclusion of land plots into organic agriculture, when organically 
produced fodder from these plots is provided (Mirecki, Wehinger, Jaklič, 2011)

The respondents answered the question „Do you see the future of agriculture in organic production?" as follows - in Figure 4.

Based on the Figure 4, it can be concluded that most of them see the future of agriculture in organic production. A possibility of developing organic production is extremely high. The village is far away from different types of pollution, and accordingly, conditions should be created that would enable obtaining a certificate for organic production for an unhindered involvement in organic plant or animal production.

In view of the fact that the techniques used in organic production do not damage the environment (Jonathan, 2009), they are characteristic of the lifestyle, the history and the tradition of small farms, so that the respondents' belief that they see (their) future of agriculture in organic production is understandable.

According to the report of the American Council for National Research (Jonathan, 2009), organic production can be economically profitable if it overcomes the following obstacles: a better approach to information, in view of its information-intensive character; establishing organic standards; a reform of the agricultural subsidies policy.

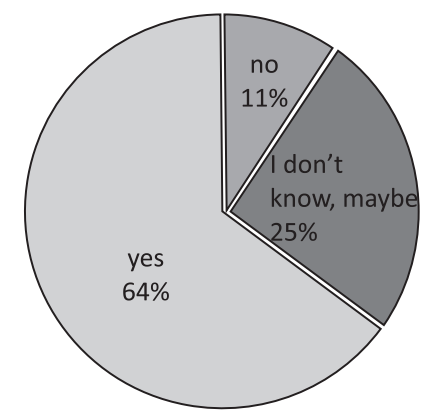

Figure 4 Do you see the future of agriculture in organic production?

Source: Authors
The above obstacles and conditions bring into question the profitability of conversion and obtaining a certificate for organic food production. According to the opinion of the inhabitants of Velebit, organic production is profitable, although it requires high costs compared to conventional production. The research results are presented in the Figure 5.

As noted before, costs in organic production are extremely high, especially at the beginning of soil preparation and organic food production. In cases when farmers opt for organic production, the key factor is obtaining a certificate, thus obtaining a possibility of selling products on the market at notably higher prices compared to the conventional ones. In order to obtain the certificate, the producer must undergo a period of the conversion of production conditions lasting from 2 to 3 years in order to create conditions for organic production. Only the soil that has not been in use for two or more years can immediately be used for organic food production. Irrigation in organic production requires the 1st or the 2 nd class water quality. Also, packaging materials for organic products must be made of natural materials and the storage conditions must be optimum, without any radiation. This process from field to storage is subject to control (Stendidž, 2009).

In addition to the above-listed conditions essential for an involvement in organic production, the inhabitants of the village of Velebit responded at the

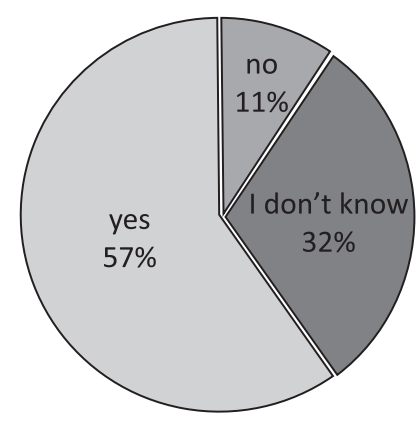

Figure 5 Is organic food production profitable?

Source: Authors 
highest percentage that organic production could be developed on their property and that there were no factors causing an inability to produce. Based on Figure 6, it can be concluded that as many as $86 \%$ of the respondents replied that it was possible to develop organic production, which is very important information, significant for this form of production.

Organic food production yields high financial revenues to producers because, depending on the degree of processing, organic products are by 20 to $40 \%$ more expensive than those produced conventionally. Also, producers who opt for this type of production must be prepared for exposing themselves to higher financial investments required for initiating production.

The potential benefits of organic production in the village of Velebit are presented in the Table 2.

This form of production is especially significant for the development of small family farms predominant in the Municipality of Kanjiža as it is the most profitable one as well. In particular, growth in demand for organic products expected in the near future creates a possibility for these producers to improve and extend their agricultural production, so that they can become competitive on the world market (Đekić, 2009). In this way, farms would gain higher returns and thus achieve a higher profit.

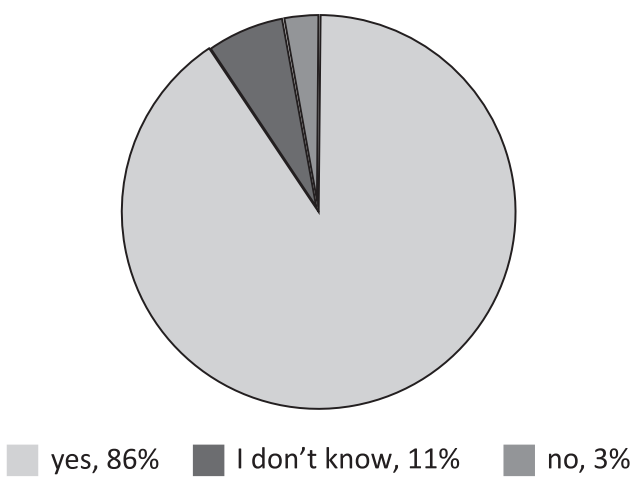

Figure 6 Can organic production be developed on your farm?

Source: Authors
Table 2 Benefits of organic agriculture

\begin{tabular}{l|l}
\hline Parameter & Possible positive changes \\
\hline Agriculture & $\begin{array}{l}\text { High-quality and safe food, stable } \\
\text { production, reduction in pests and } \\
\text { diseases } \\
\text { Reduced pollution, preserved } \\
\text { ecosystems, the standards of the } \\
\text { environment harmonized with the } \\
\text { standards of production } \\
\text { Health care, higher education levels of } \\
\text { producers, a better quality of work } \\
\text { She stable local economy, increased } \\
\text { Economic }\end{array}$ \\
conditions & \multicolumn{2}{l}{ revenue, reduced risks } \\
\hline
\end{tabular}

Source: Authors

\section{CONCLUSION}

Poverty as a phenomenon has several aspects, the rural aspect being one of them. This aspect is especially interesting for RS, as it has been noted that rural poverty is more manifest than urban poverty and simultaneously harder to overcome, i.e. reduce.

Rural poverty is actually one of the main characteristics of poverty in RS (Mreža za podršku ruralnom razvoju, 2015), as confirmed by the results of a survey on the living standards conducted in 2007, according to which the percentage of the poor living in rural areas has grown to over $61 \%$ (compared to $55 \%$ in 2002). According to the same survey, poverty is still twice as present in rural areas as in urban ones. From the aspect of poverty, the most vulnerable categories of the rural population are: farmers earning their income from farming only, old persons, pensioners, women and the young, and displaced persons. It is symptomatic that rural poverty has also recorded growth in agriculturally the most developed areas - parts of the Autonomous Province of Vojvodina.

The Serbian countryside is currently facing the problems of ageing, impoverishment and the population depletion as a consequence of migrations from villages to towns. The countryside is first abandoned by the most able and the most vital section of the population, thus contributing to the specific spiral of rural poverty. 
By its characteristics, the village of Velebit belongs to typical Serbian villages. To prevent the dramatic fate of disappearance, the village should be revived. The research presented in this paper has demonstrated that this is possible.

Particularly, both starting hypotheses of the paper have been proved: the inhabitants of the small rural community (the village of Velebit) really want to stay in their village, to live and work there, (over 50\%), whereas only $21.43 \%$ of the respondents assessed life in the countryside as bad or very bad.The surveyed villagers have some knowledge of organic agricultural production and its importance for survival and raising the level of the quality of life in the countryside and would venture into setting up this form of production, but they cannot do it by themselves $(64 \%$ of the respondents see the future of agriculture in organic production, $57 \%$ of them believe this production to be profitable, and as many as $86 \%$ of them believe that organic production can be developed on their farms).

The village of Velebit has potentials (natural resources) and the will to organize organic agricultural production so as to provide a sustainable future, but the villagers lack sufficient capacities in the form of knowledge, information and financial capital necessary for this form of production.

The results of this research can be useful for bearers and creators of economic policies (especially rural and social ones) to more rapidly and more efficiently implement their strategies pertaining to sustainable rural development and reduction in poverty, network and make all relevant information about small rural communities and their potentials available because the benefits of organic production are multiple and longlasting.

\section{REFERENCES}

Aleksić, M. (2013). Potencijali organske poljoprivrede u opštini Kanjiža. Neobjavljeni master rad. Ekonomski fakultet u Subotici Univerziteta u Novom Sadu, Subotica, Republika Srbija.

Bogdanov, N. (2007). Mala ruralna domaćinstva u Srbiji. Beograd, Republika Srbija: Program Ujedinjenih nacija za razvoj.
Božić, D., Bogdanov, N. i Ševarlić, M. (2011). Ekonomika poljoprivrede. Beograd, Republika Srbija: Poljoprvredni fakultet.

Đekić, I. (2009). Uproaljanje zaštitom životne sredine u proizvodnji hrane. Beograd, Republika Srbija: Poljoprivredni fakultet Univerziteta u Beogradu.

Gidens, A. (2005). Odbegli svet: kako globalizacija preoblikuje naše živote. Beograd, Republika Srbija: Stubovi kulture.

Jonathan, M. H. (2009). Ekonomija životne sredine i prirodnih resursa. Beograd, Republika Srbija: Data status.

Komazec, Lj. (2009). Socijalno-etički diskurs ekološke krize u Srbiji. U S. Grk, (Ur.), Srbija i Evropa: ekonomija, društvo $i$ politika (str. 127-139). Beograd, Republika Srbija: Institut društvenih nauka.

Komazec, Lj. (2011). Održivi razvoj Srbije između paradigme i realnosti. U S. Grk, (Ur.), Srbija i svet: razvoj i integracije (str. 109-125). Beograd, Republika Srbija: Institut društvenih nauka.

Komazec, Lj. i Marjanov Panjević, R. (2011). Projekat Socijalna laboratorija - Opština Kanjiža.

Mander, J. i Goldsmith, E. (2003). Globalizacija argumenti protiv. Beograd, Republika Srbija: CLIO.

Mirecki, N. Wehinger, T. i Jaklič, M. (Ur.). (2011). Priručnik za organsku proizvodnju za poljoprivredne proizvođače. Podgorica, Crna Gora: Biotehnički fakultet Podgorica.

Ministarstvo za nauku i tehnološki razvoj. (2009). Održivi razvoj Srbije: Naša zajednička budućnost. Beograd, Republika Srbija.

Mreža za podršku ruralnom razvoju. (2015). Nacionalni program ruralnog razvoja. www.ruralinfoserbia.rs, str. 16

Pečujlić, M. (2002). Globalizacija: dva lika sveta. Beograd, Republika Srbija: Beogradska otvorena škola.

Radić, J. (2007). Ekonomija rada i socijalna politika Evropske unije. Subotica, Republika Srbija: Ekonomski fakultet.

Reinert, E. S. (2004). Globalna ekonomija: Kako su bogati postali bogati i zašto siromašni postaju siromašniji. Beograd, Republika Srbija: Čigoja štampa.

Ristic, L. (2013). Strategic management of sustainable rural development in the Republic of Serbia. Economic Horizons, 15(3), 233-248, doi: 10.5937/ekonhor1303229R.

Serbia organica. (2013). Oraganska poljopriveda. www. serbiaorganica.

Stendidž, T. (2009). Jestiva istorija čovečanstva. Beograd, 
Republika Srbija: Geopoetika.

Vlada Republike Srbije. (2003). Strategija za smanjenje siromaštva u Srbiji. www.srbija.gov.rs, str. 114, 147.
Vlada Republike Srbije. (2014). Drugi nacionalni izveštaj o socijalnom ukuljučivanju i smanjenju siromaštva u Srbiji. www. ljudskaprava.gov.rs

Received on $30^{\text {th }}$ June 2015 , after two revision, accepted for publication on $17^{\text {th }}$ August 2015.

Published online on $25^{\text {th }}$ August 2015

Ljubica Komazec is a Professor at the Faculty of Economics in Subotica, Univesity of Novi Sad, The Republic of Serbia, where she teaches at all levels of studies, in the courses of Economics of Enterprise, Environment Management, Ecological Urban Engineering and Cost Theories. She obtained her PhD in the field of economic efficiency and has published a large number of research studies in the field of sustainable development, environment management and corporate social responsibility.

Marko Aleksic is a demonstrator at the Faculty of Economics in Subotica, Univesity of Novi Sad, The Republic of Serbia, in the courses of Management in Agribusiness, Management of Organic Food Production, Environment Management and Agribusiness Strategy. 


\title{
ORGANSKA POLJOPRIVREDNA PROIZVODNJA U FUNKCIJI SMANJENJA RURALNOG SIROMAŠTVA - PRIMER VOJVOĐANSKOG SELA VELEBIT
}

\author{
Ljubica Komazec* i Marko Aleksić \\ Ekonomski fakultet u Subotici Univerziteta u Novom Sadu
}

\begin{abstract}
Obespokojavajuće medijske slike o propadanju i nestajanju sela u gotovo svim delovima Republike Srbije (RS), kao posledica nedovoljnog napretka u implementaciji paradigme ruralnog načina života, poželjnog i potrebnog svakoj zajednici i svakoj ekonomiji, znak su za uzbunu svakom subjektu društva da učini sve što je u njegovoj nadležnosti (moći) kako bi se ovi nepovoljni procesi zaustavili. U radu su istraženi potencijali jedne male ruralne zajednice $u$ RS da opstane i da se razvije na dobrobit nje same i društva u celini. Uvažavajući činjenicu da relevantni društveni dokumenti imaju svoj značaj i svoju ulogu u svim društvenim procesima, ali da nisu dovoljan uslov za njihovo unapređenje, autori su anketirali i intervjuisali meštane vojvođanskog sela Velebit o njihovim stavovima, potencijalima, potrebama i ograničenijima u vezi sa zasnivanjem i trajnijim bavljenjem organskom poljoprivrednom proizvodnjom kako bi dotično selo opstalo i unapredilo svoj socijalni, ekonomski i društveni položaj. Rezultati istraživanja pokazuju da meštani sela Velebit jesu zainteresovani da na selu ostanu, da zasnuju organsku poljoprivrednu proizvodnju, ali da im je potrebna pomoć, kako savetodavna, tako i finansijska, jer sami za to nemaju dovoljno kapaciteta.
\end{abstract}

Ključne reči: organska proizvodnja, stopa siromaštva, ruralne sredine, održivi razvoj

JEL Classification: Q01, Q18, Q58

\section{UVOD}

Prošlo je 15 godina od definisanja i projektovanja humane i univerzalne ideje trajnog i pravednog mira u svetu, a u skladu sa ciljevima i principima Milenijumske deklaracije Ujedinjenih nacija, potpisane septembra 2000. godine od strane svih zemalja članica Ujedinjenih nacija. Globalni konsenzus o održivom

\footnotetext{
* Korespondencija: Lj. Komazec, Ekonomski fakultet u Subotici Univerziteta u Novom Sadu, Segedinski put 9-11, 24000 Subotica, Republika Srbija; e-mail: ljkomazec@ef.uns.ac.rs
}

razvoju i opstanku na planeti Zemlji nezamisliv je bez pravičnosti i smanjenja protivrečnosti savremenog sveta u pogledu kvaliteta života, te međunacionalne, ali i međugeneracijske solidarnosti (Pečlujić, 2002; Mander i Goldsmith, 2003; Gidens 2005). Milenijumska deklaracija trasirala je međunarodne odnose u XXI veku na principima slobode, jednakosti, solidarnosti, tolerancije, poštovanja prirode i podele odgovornosti, sugerišući zemljama u razvoju (u kojima su siromaštvo i isključenost, te sa njima povezani drugi problemi, naročito, izraženi) da definišu sopstvene nacionalne strategije razvoja sa merama i alternativama kojima bi 
postigle milenijumske ciljeve razvoja (Komazec, 2009; Komazec, 2011).

Vlada Republike Srbije je Milenijumske ciljeve razvoja uključila u Strategiju za smanjenje siromaštva (Vlada Republike Srbije, 2003), a 2005. godine je izvršena ocena trendova i napretka $u$ postizanju svakog milenijumskog cilja. Do sada je predstavila dva nacionalna izveštaja o socijalnom uključivanju i smanjenju siromaštva u Republici Srbiji, jedan 2011. godine (za period 2008-2010. godine), a drugi 2014. godine (za period 2011-2014. godine). Apostrofirajući značaj dostizanja evropskog socijalnog modela, a u cilju približavanja evrointegracijama (Radić, 2007), Republika Srbija (njeni organi i institucije) je preduzela značajne korake $\mathrm{u}$ procesima razvoja relevantnih politika, institucionalnih i regulatornih tela definisanih strateškim okvirom Evropske unije, poznatim pod nazivom Evropa 2020: Strategija pametnog, održivog i inkluzivnog rasta.

Navedena strategija u fokus stavlja 11 područja važnih za uspešniju koordinaciju ekonomske i socijalne politke, a među njima je i ruralni razvoj (Bogdanov, 2007). Cilj strategije u ovoj oblasti jeste pomaganje poljoprivrednicima u povećanju konkurentnosti i promovisanju razvoja ruralnih područaja, posebno $\mathrm{u}$ manje atraktivnim regionima. U skladu sa ovim ciljevima, finansiranje poljoprivrednika usmerava se na zaštitu životne sredine i na kvalitet proizvoda. Osnivanje evropskog poljoprivrednog fonda za ruralni razvoj potvrda je ozbiljnosti i posvećenosti definisanoj ideji (Ristic, 2013).

Polazeći od strateških nacionalnih opredeljenja za smanjenje siromaštva u RS, posebno, ruralnog, i faktičkog, vrlo nepovoljnog stanja u ovoj oblasti, tema istraživanja je vrtlog ruralnog siromaštva, kao posledica dugogodišnjeg demografskog pražnjenja sela, njegovog starenja i ukupnog ekonomskog propadanja.

Cilj istraživanja je da se dokaže da je te negativne procese moguće zaustaviti uz odgovarajuću angažovanost svih zainteresovanih subjekata, kako samih meštana male ruralne zajednice, tako i društva u celini.

Uvažavajući predmet i cilj istraživanja, u radu se polazi od sledećih hipoteza:
H1: Stanovnici male ruralne zajednice - sela Velebit u AP Vojvodina, su zainteresovani da ostanu da žive $\mathrm{u}$ svom selu i da unaprede kvalitet života $\mathrm{u}$ njemu.

H2: Stanovnici dotičnog sela imaju određena znanja i svest o rešavanju problema opstanka sela, ali nemaju dovoljno kapaciteta da ih rešavaju sami.

U procesu istraživanja korišćene su metode neposrednog terenskog anketiranja i intervjuisanja meštana u odabranom selu, kao i korespodentne matematičko-statističke metode obrade i prezentovanja dobijenih podataka.

\section{DOMETI STRATEGIJE ZA SMANJENJE SIROMAŠTVA U REPUBLICI SRBIJI - INSTITUCIONALNA (NE)MOĆ}

Strategija Vlade Republike Srbije za smanjenje siromaštva (Vlada Republike Srbije, 2003) projektovala je tri osnovna pravca (cilja), među kojima je i borba protiv siromaštva i poboljšanje sistema socijalne zaštite najugroženijih društvenih grupa, pri čemu je naglašeno da je siromaštvo u RS složenije i specifičnije ne samo $u$ odnosu na siromaštvo $u$ razvijenim zemljama (Ministarstvo za nauku i tehnološki razvoj, 2009), već i u zemljama u tranziciji, a kao posledica izrazito složenih i dramatičnih, političkih i ekonomskih procesa koje je društvo RS doživelo u relativno kratkom roku (ratovi, sankcije, inflacija, agresija NATO pakta, svojinska transformacija, strukturna privredna prilagođavanja i drugo). Navedeni procesi su doveli do pojave široko rasprostranjenog siromaštva u svim društvenim grupama i socijalnim slojevima.

$\mathrm{Na}$ osnovu istraživanja u funkciji oblikovanja i donošenja strategije za smanjenje siromaštva, detektovane su kategorije stanovništva u RS koje su najviše izložene riziku siromaštva (Vlada Republike Srbije, 2003): neobrazovano stanovništvo; nezaposlena i izdržavana lica; stara lica (65+) i deca; domaćinstva sa pet i više članova; staračka jednočlana i dvočlana domaćinstva, posebno u ruralnim područjima; zemljoradnički penzioneri, naročito, $\mathrm{u}$ ruralnim sredinama; stanovnici ruralnih područja jugoistočne i zapadne RS; Romi, interno raseljena lica, osobe sa invaliditetom. 
Lako je primetiti, da se gotovo sve navedene kategorije ukrštaju sa ruralnim stanovništvom.

Ruralni aspekti siromaštva dobijaju na značaju ako se uzmu u obzir faktori-trendovi $\mathrm{u}$ dominantnim demografskim i ekonomskim procesima na teritoriji RS koji za posledicu imaju ruralno siromaštvo (Vlada Republike Srbije, 2003): demografsko pražnjenje seoskih područja; unutarregionalne demografske diferencijacije i atomizacija naselja $u$ nerazvijenom seoskom području.

Uvažavajući nesporni značaj društvenih dokumenata (strategija, akcionih planova, izveštaja) u procesima rešavanja društvenih problema, istraživanje $u$ ovom radu se oslanja na: Drugi nacionalni izveštaj o socijalnom uključivanju i smanjenju siromaštva u Republici Srbiji, (Vlada Republike Srbije, 2014) i Projekat: "Socijalna laboratorija - opština Kanjiža” (Komazec, Marjanov i Panjević, 2011).

Istraživačke motive pokrenuli su zaključci i predlozi mera Drugog nacionalnog izveštaja o socijalnom uključivanju i smanjenju siromaštva, a posebno sledeći (Vlada Republike Srbije, 2014):

- Demografska erozija jedna je od ključnih osobina ruralnih područja. Prosečna gustina naseljenosti u ruralnim područjima iznosi 50 stanovnika/ $\mathrm{km}^{2}$. Učešće ruralnog stanovništva u ukupnom stanovništvu iznosi $40,56 \%$, a prosečna starost u ruralnim područjima je 43,6 godina. Indeks starenja u 2010. iznosio je $130 \mathrm{u}$ odnosu na 94 u gradskim naseljima, a $82,5 \%$ naselja imalo je negativan prirodni priraštaj. Manje od 100 stanovnika ima 986 naselja, dok u 1.458 naselja (31\%) nije rođeno nijedno dete, a 31,8\% ukupno živorođenih i čak 47,38\% umrlih u 2012. je iz ruralnih područja.

- Ako posmatramo nivo apsolutnog siromaštva u periodu 2011-2013, procenat siromašnog stanovništva je duplo veći u ruralnim u odnosu na gradska područja. U 2013, 12\% siromaštva ruralnih područja bilo je apsolutno siromašno u odnosu na 6,3\% u gradskim područjima. Gazdinstva veličine od jednog do pet hektara negativnije su reagovala na ekonomsku krizu. Prema Popisu poljoprivrede 2012. godine, više od $76 \%$ gazdinstava spada u kategoriju koja poseduje manje od 5 hektara, a raspolažu sa samo $30 \%$ površina. U Republici Srbiji, najviše je porodičnih gazdinstava koja koriste do dva hektara poljoprivrednog zemljišta $(48,2 \%$ od ukupnog broja), i ova gazdinstva obrađuju više od $9 \%$ poljoprivrednog zemljišta. U Evropi skoro $70 \%$ gazdinstva ima manje od pet hektara poljoprivrednog zemljišta.

- Stanovništvo u ruralnim sredinama, u poređenju sa gradskim, pokazuje više stope aktivnosti i zaposlenosti, kao i niže stope nezaposlenosti i neaktivnosti (Reinert, 2004). Stopa nezaposlenosti ruralnog stanovništva (15-64 godine) u 2011. godini iznosila je 21,9\% i beleži smanjenje u 2013. godini, kada je iznosila 19,9\%. Stopa zaposlenosti u istom periodu porasla je za $2,8 \%$, sa $47,4 \%$ na $50,2 \%$. Broj samozaposlenih lica u ruralnim područjima porastao je za 3,5\% u periodu 2011-2013, i duplo je veći nego u gradskim područjima, dok se broj pomažućih članova domaćinstva kretao oko $16 \%$ u posmatranom periodu. Gotovo celokupna neformalna zaposlenost odvija se $u$ sektorima poljoprivrede, građevinarstva i u sektoru usluga i smeštaja, a poljoprivreda $\mathrm{u}$ ruralnim područjima doprinosi sa $64,4 \%$. Stopa rizika od siromaštva prema najčešćem statusu na tržištu rada kod samozaposlenih lica, u koje spadaju i poljoprivrednici, je veća, i iznosi 38,3\%.

Drugi, za istraživače značajniji motiv bio je da pokušaju da, u maloj ruralnoj zajednici, utvrde uzroke zaostajanja u razvoju, potencijale za izlazak iz zone siromaštva, stavove i percepciju stanovništva o ruralnom okruženju, mogućnosti da, uz pomoć relevantnih institucija, iskoriste šanse koje imaju. Odabrano je selo Velebit u AP Vojvodini (Aleksić, 2013).

\section{O VOJVOĐANSKOM SELU VELEBIT}

Selo Velebit pripada opštini Kanjiža, a nalazi se između Palićkog jezera i Banje Kanjiže, na nadmorskoj visini od 106 metara. Selo je prepoznatliivo po kvalitetu vazdušne banje, kao i kvalitetnom zemljištu pogodnom za organsku poljoprivredu.

Istraživanjem je obuhvaćeno 28 domaćinstava, sa starosnom i obrazovnom strukturom prikazanom $\mathrm{u}$ Tabeli 1. 
Tabela 1 Starosna struktura i nivo obrazovanja anketiranih članova domaćinstva

\begin{tabular}{|c|c|c|c|c|c|c|c|c|c|c|}
\hline \multirow{2}{*}{$\begin{array}{l}\text { Godine } \\
\text { Pol }\end{array}$} & \multicolumn{2}{|c|}{ Do 14} & \multicolumn{2}{|c|}{$15-24$} & \multicolumn{2}{|c|}{$25-49$} & \multicolumn{2}{|c|}{$50-64$} & \multicolumn{2}{|c|}{$65+$} \\
\hline & $M$ & $\check{Z}$ & $M$ & $\check{z}$ & $M$ & $\check{Z}$ & $M$ & ž & $M$ & $\check{z}$ \\
\hline Bez škole & 4 & & & & & & & & & \\
\hline Osnova škola & 1 & 1 & & & 2 & 1 & 2 & 2 & 1 & 2 \\
\hline Srednja škola (3g) & & & 2 & 1 & 3 & 2 & 9 & 5 & 1 & \\
\hline Srednja škola (4g) & & & 6 & 2 & 7 & 5 & 7 & 5 & & 1 \\
\hline Visoka škola & & & & 1 & 4 & 7 & 1 & 1 & & \\
\hline
\end{tabular}

Izvor: Autori

Na osnovu Tabele 1, može se primetiti da najveći broj stanovnika čine ljudi između 25 i 64 godine, veći deo ženske populacije je starosne dobi od 25 do 49 godina, dok je kod muškaraca, većina onih koji imaju preko 50 godina. Što se tiče nivoa obrazovanja, većina ženske populacije ima završenu višu školu ili fakultet, dok je kod muške populacije, većina završila trogodišnju ili četvorogodišnju školu. Izrazito je mali broj dece i učenika, što potvrđuje činjenica da samo šestoro đaka pohađa osnovnu školu koja se nalazi u selu.

Anketirani ispitanci su procenili kvalitet života na selu na različite načine - Slika 1.

Iako je manji deo ispitanika $(46,43 \%)$ život na selu ocenio kao dobar ili veoma dobar, najveći deo njih se ne bi odselio iz sela - Slika 2.

Problem u selu predstavlja veći broj napuštenih kuća, čiji vlasnici žive van sela, te dolaze nedeljno, mesečno, ili ne dolaze mesecima, pa kuće usled neodržavanja postepeno propadaju. Iako su kuće relativno jeftine, skoro da nema novih doseljenika u ovo selo. Veći broj meštana iz ovog sela ide $\mathrm{u}$ gradove prvenstveno tragajući za poslom i radi daljeg školovanja dece. Trend napuštanja sela u RS radi odlaska u veće gradove nije zaobišao ni ovo selo, te ono postepeno stari. Prosečna starost stanovništva u ovom selu se povećava i iznosi 50 godina. Mladih u ovom selu je sve manje te škola i obdanište imaju sve manje polaznika.

Na pitanje: Šta bi Vam pomoglo da živite bolje, ispitanici su odgovorili na sledeći način - Slika 3.

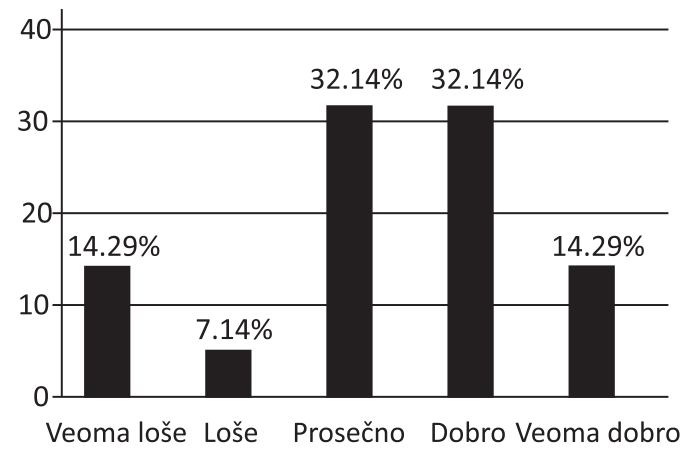

Slika 1 Kako procenjujete kvalitet života na selu?

Izvor: Autori

Na osnovu Slike 3 može da se zaključi da je stanovnicima sela neophodna bolja organizovanost tržišta, kako bi obezbedili više izvora prihoda, kao i da svoju budućnost vide $u$ poljoprivredi. Pristup kreditima neophodan je domaćinstvima koja svoju budućnost vide $\mathrm{u}$ pokretanju privatnog posla ili na poljoprivrednim gazdinstvima. Pomenuta domaćinstva, koja planiraju pokretanje privatnog posla van poljoprivrede navode da im je bitan i bolji pristup informacijama, kao pomoć za poboljšavanje postojećeg stanja (Bogdanov, 2007). Međutim, kao glavni preduslov za unapređenje poljoprivredne proizvodnje, navode veću ulogu države i njenih podsticajnih mera.

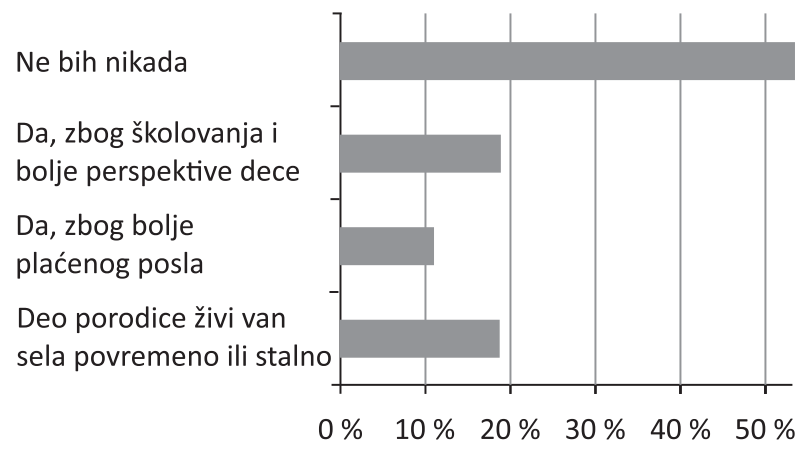

Slika 2 Da li biste se odslelili iz Vašeg sela?

Izvor: Autori 


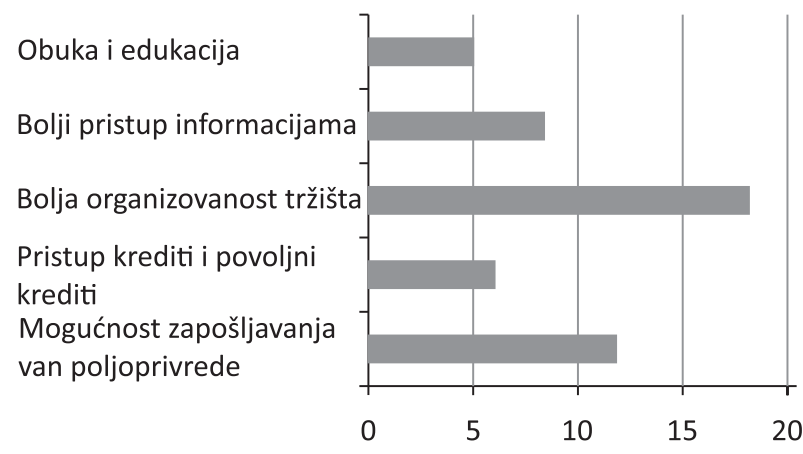

Slika 3 Šta bi Vam pomoglo da živite bolje?

Izvor: Autori

\section{ORGANSKA POLJOPRIVREDNA PROIZVODNJA U SELU VELEBIT - PERSPEKTIVE I ŠANSE}

Organskom proizvodnjom čuva se zdravlje ljudi i životne okoline, kao i čitavog agro-eko sistema. Proizvodnja se zasniva na racionalnom korišćenju resursa, upotrebi što više obnovljivih resursa, zaštiti životni sredine. U ovom sistemu proizvodnje se isključuje korišćenje bilo kakvih sintetizovanih sredstava (Serbia organica, 2013).

Organska proizvodnja ima sledeće odlike: zasniva se na prirodnim procesima i upotrebi organskih i prirodnih mineralnih materija; ne mogu se koristiti sredstva sintetičko-hemijskog porekla, osim u slučajevima propisanih zakonom; ne mogu se koristiti genetski modifikovani organizmi i njihovi derivati; materijal za reprodukciju (seme, sadni materijal, podmladak, jaja) koji se primenjuje $u$ organskoj proizvodnji, mora biti proizveden na organski način; organska poljoprivreda je sistem ekološkog upravljanja proizvodnjom, kojim se unapređuje biodiverzitet, kruženje materije $u$ prirodi, biološka aktivnost zemljišta, zaštita životne sredine; prostorna izolacija parcela, stočarskih farmi i prerađivačkih pogona od mogućih izvora zagađenja; nezagađeno zemljište čiji je sadržaj štetnih materija ispod propisanih maksimalno dozvoljenih područja; propisani kvalitet vode za navodnjavanje i minimalna zagađenost vazduha proizvodnog područja; uključivanje zemljišne parcele u organsku proizvodnju može se započeti odmah - ako parcela nije korišćena $\mathrm{u}$ poslednje dve, odnosno, $\mathrm{u}$ poslednje tri godine kod dugogodišnjih zasada, ili je korišćena bez upotreba sredstava sintetičko-hemijskog porekla, ako jesu period konverzije je dve, odnosno, tri godine; organska proizvodnja može se zasnivati na proizvodnim jedinicama u čijem sastavu se nalaze pašnjaci ili drugo zemljište na kome se proizvodi stočna hrana ili se obezbeđuje hrana za koju je izdat sertifikat (Božić, Bogdanov i Ševarlić, 2011); uključivanje stočarske proizvodnje $\mathrm{u}$ organsku proizvodnju može početi najmanje godinu dana od dana uključivanja zemljišnih parcela $\mathrm{u}$ organsku poljoprivredu, kada se obezbedi organski proizvedena hrana za stoku sa navedenih parcela (Mirecki, Wehinger i Jaklič, 2011).

$\mathrm{Na}$ pitanje iz ankete: $\mathrm{Da}$ li vidite budućnost poljoprivrede $\mathrm{u}$ organskoj proizvodnji? ispitanici su odgovorili na načine prikazane na Slici 4.

Na osnovu Slike 4, može se zaključiti da većina njih vidi budućnost poljoprivrede u organskoj proizvodnji. Mogućnost za razvoj organske proizvodnje je izuzetno velika. Selo je udaljeno od različitih vrsta zagađenja, te je neophodno stvoriti uslove koji bi omogućili dobijanje sertifikata za nesmetano bavljenje organskom biljnom ili stočarskom proizvodnjom.

S obzirom na činjenicu da tehnike koje se primenjuju u organskoj proizvodnji ne oštećuju životnu sredinu (Jonathan, 2009), one su svojstvene načinu života, istoriji i tradiciji malih poljoprivrednih poseda, te

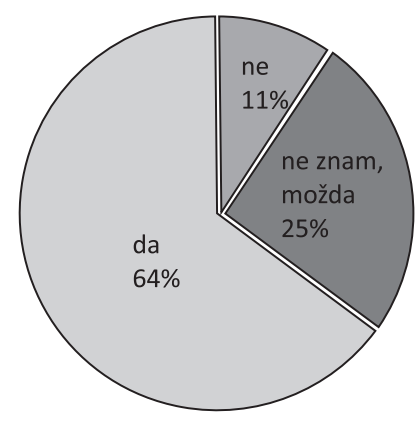

Slika 4 Da li vidite budućnost poljoprivrede u organskoj proizvodnji?

Izvor: Autori 
je razumljivo uverenje anketiranih da vide svoju budućnost poljoprivrede u organskoj proizvodnji.

Prema izveštaju Saveta za nacionalna istraživanja Sjedinjenih Američkih Država (Jonathan, 2009), organska proizvodnja može da bude i ekonomski isplativa ako se prevaziđu sledeće prepreke: veći pristup informacijama; utvrđivanje organskih standarda; reforma politike poljoprivrednih subvencija.

Navedene prepreke dovode $\mathrm{u}$ pitanje isplativost konverzije i dobijanje sertifikata za mogućnost proizvodnje hrane na organski način. Prema mišljenju meštana sela Velebit, organska proizvodnja je isplativa, iako iziskuje velike troškove, jer donosi i visoku cenu u odnosu na konvencionalni proizvod - Slika 5.

Kako je već napomenuto, troškovi u organskoj proizvodnji su izuzetno visoki, posebno na početku pripreme zemljišta i proizvodnje hrane na ogranski način. U slučaju kada se poljoprivredni proizvođač odluči za organsku proizvodnju, za njega je od presudnog značaja dobijanje sertifikata, čime se stiče mogućnost plasiranja proizvoda na tržište po višim cenama $\mathrm{u}$ odnosu na konvencionalno proizvedena dobra. Da bi se dobio certifikat, proizvođač mora da prođe kroz period konverzije uslova proizvodnje od 2 do 3 godine, kako bi se stvorili uslovi za organsku proizvodnju. Jedino zemljište koje nije korišćeno dve ili više godina se može koristiti odmah za organsku

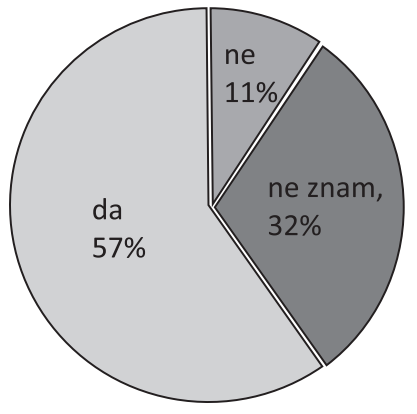

Slika 5 Da li se isplati proizvoditi hranu na organski način? proizvodnju hrane. Navodnjavanje $\mathrm{u}$ organskoj proizvodnji zahteva kvalitet vode I ili II klase. Takođe, ambalaža u koju se pakuje organski proizvod mora biti od prirodnih materijala, a uslovi čuvanja moraju biti optimalni bez bilo kakvih zračenja. Ovaj proces od njive do čuvanja je podložan kontroli (Stendidž, 2009).

Pored navedenih uslova koji su nepohodni za bavljenje organskim vidom proizvodnje, meštani sela Velebit su u najvećem procentu odgovorili da je, po njihovom mišljenju, na njihovim zemljištima moguće razviti organsku proizvodnju, i da ne postoje faktori koji bi uticali na nemogućnost proizvodnje. Na osnovu Slike 6, može se uočiti da je čak $86 \%$ ispitanika odgovorilo da je moguće razviti organsku proizvodnju, što predstavlja značajan podatak za ovaj vid proizvodnje.

Organska proizvodnja hrane donosi veliku dobit proizvođačima zato što su proizvodi proizvedeni organskim putem skuplji od proizvoda proizvedenih na konvencionalan način za 20 do $40 \%$ u zavisnosti od stepena prerade. Takođe, proizvođači koji se odluče za ovu vrstu proizvodnje moraju da se pripreme za veća finanasijska ulaganja, neophodna za pokretanje proizvodnje.

Potencijalne koristi od organske proizvodnje u selu Velebit prezentovane su u Tabeli 2.

Za razvoj malih porodičnih farmi koje preovlađuju u opštini Kanjiža, naročito je značajan ovaj vid

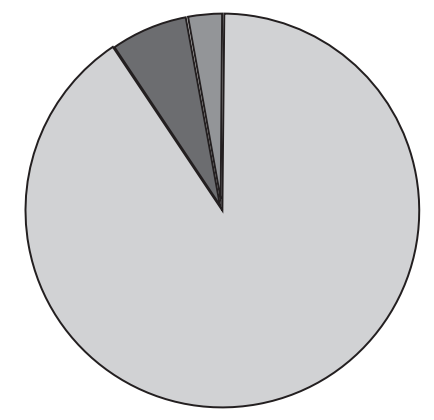

da, $86 \%$

ne znam, 11\%

ne, $3 \%$

Slika 6 Da li je moguće na Vašem gazdinstvu razviti organsku proizvodnju?

Izvor: Autori 
Tabela 2 Koristi organske poljoprivrede

\begin{tabular}{|c|c|}
\hline Parametar & Moguće pozitivne promene \\
\hline Poljoprivreda & $\begin{array}{l}\text { Visoko kvalitetna i bezbedna hrana, } \\
\text { stabilna proizvodnja, smanjenje } \\
\text { štetočina i bolesti }\end{array}$ \\
\hline Životna sredina & $\begin{array}{l}\text { Smanjenje zagađenja, očuvanje agro- } \\
\text { ekosistema, usaglašenost standarda } \\
\text { životne sredine sa standardima } \\
\text { proizvodnje }\end{array}$ \\
\hline Društveni uslovi & $\begin{array}{l}\text { Briga o zdravlja, viši nivo edukacija } \\
\text { proizvođača, bolji kvalitet rada }\end{array}$ \\
\hline Ekonomski uslovi & $\begin{array}{l}\text { Stabilna lokalna ekonomija, uvećanje } \\
\text { prihoda, smanjen rizik }\end{array}$ \\
\hline
\end{tabular}

Izvor: Autori

proizvodnje, s obzirom da je i najrentabilniji. Naime, rast tražnje za organskim proizvodima koji se očekuje u bližoj budućnosti stvara mogućnost ovim proizvođačima da unaprede i povećaju svoju poljoprivrednu proizvodnju kako bi mogli postati konkurentni na svetskom tržištu (Đekić, 2009). Na taj način bi poljoprivredna gazdinstva ubirala veće prihode, a samim tim i ostvarivala veći profit.

\section{ZAKLJUČAK}

Siromaštvo kao fenomen ima više aspekata, a jedan od njih je i ruralni aspekt. Za Republiku Srbiju je ovaj aspekt posebno interesantan, jer je uočeno da je ruralno siromaštvo izraženije od urbanog, i teže se pravazilazi, tj. smanjuje.

Ruralno siromaštvo je jedna od osnovnih karakteristika siromaštva u RS (Mreža za podršku ruralnom razvoju, 2015), što su potvrdili rezultati ankete o životnom standardu iz 2007, prema kojima je procenat siromašnih koji živi u rulanim područjima porastao na preko $61 \%$ (u odnosu na $55 \%$ u 2002.). Prema istoj anketi, siromaštvo je i dalje dvostruko više rasprostranjeno $u$ ruralnim nego $u$ urbanim područjima. Sa aspekta siromaštva, najosetliivije kategorije ruralnog stanovništva su: poljoprivrednici koji prihode ostvaruju isključivo od poljoprivrede, starija lica, penzioneri, žene i mladi, kao i raseljena lica. Simptomatično je da je ruralno siromaštvo zabeležilo rast i u poljoprivredno najrazvijenijim područjima AP Vojvodine.

Selo u RS danas je suočeno sa procesima starenja, siromašenja i pražnjenja, a kao posledica migratornih kretanja iz sela ka gradovima. Sela napušta najpre najsposobniji i najvitalniji deo stanovništva, i time doprinose specifičnoj spirali ruralnog siromaštva.

Vojvođansko selo Velebit, po svim svojim obeležjima, spada u tipična sela u RS. Kako ne bi doživelo nestajanje, selo bi trebalo oživeti. Istraživanja prezentovana $u$ ovom radu pokazala su da je to moguće.

Obe polazne hipoteze rada su dokazane: stanovnici male ruralne zajednice (selo Velebit) žele da ostanu da žive i rade u svom selu preko (50\%), odnosno, 21,43\% ispitanika je život na selu ocenilo kao loš ili veoma loš. Takođe, anketirani seljani poseduju izvesna znanja o organskoj poljoprivrednoj proizvodnji i njenom značaju za opstanak i podizanje nivoa kvaliteta života na selu, upustili bi se u zasnivanje ovog vida proizvodnje, ali ne mogu sami: (64\% ispitanika vidi budućnost poljoprivrede u organskoj proizvodnji, njih $57 \%$ smatra da je ova proizvodnja isplativa, a $86 \%$ smatra da je na njihovom gazdinstvu moguće razviti organsku proizvodnju).

Iz istraživanja proizilazi da u selu Velebit postoje prirodni resursi i volja meštana da se organizuje organska poljoprivredna proizvodnja, kako bi se selu obezbedila održiva budućnost, ali da meštani nemaju dovoljno znanja, informacija i finansijskog kapitala za ovaj vid proizvodnje.

Zaključci istraživanja se mogu smatrati korisnim za kreatore i nosioce ekonomske politike (posebno, ruralne i socijalne) da brže i efikasnije implementiraju svoje strategije koje se odnose na održivi ruralni razvoj i smanjenje siromaštva, da učine dostupnijim relevantne informacije o malim ruralnim zajednicama i njihovim potencijalima, jer su koristi od organske proizvodnje višestruke i dugoročne.

\section{REFERENCE}

Aleksić, M. (2013). Potencijali organske poljoprivrede u opštini Kanjiža. Neobjavljeni master rad. Ekonomski fakultet u Subotici Univerziteta u Novom Sadu, Subotica, Republika 
Srbija.

Bogdanov, N. (2007). Mala ruralna domaćinstva u Srbiji. Beograd, Republika Srbija: Program Ujedinjenih nacija za razvoj.

Božić, D., Bogdanov, N. i Ševarlić, M. (2011). Ekonomika poljoprivrede. Beograd, Republika Srbija: Poljoprvredni fakultet.

Đekić, I. (2009). Uproaljanje zašstitom životne sredine u proizvodnji hrane. Beograd, Republika Srbija: Poljoprivredni fakultet Univerziteta u Beogradu.

Gidens, A. (2005). Odbegli svet: kako globalizacija preoblikuje naše živote. Beograd, Republika Srbija: Stubovi kulture.

Jonathan, M. H. (2009). Ekonomija životne sredine i prirodnih resursa. Beograd, Republika Srbija: Data status.

Komazec, Lj. (2009). Socijalno-etički diskurs ekološke krize u Srbiji. U S. Grk, (Ur.), Srbija i Evropa: ekonomija, društvo $i$ politika (str. 127-139). Beograd, Republika Srbija: Institut društvenih nauka.

Komazec, Lj. (2011). Održivi razvoj Srbije između paradigme i realnosti. U S. Grk, (Ur.), Srbija i svet: razvoj i integracije (str. 109-125). Beograd, Republika Srbija: Institut društvenih nauka.

Komazec, Lj. i Marjanov Panjević, R. (2011). Projekat Socijalna laboratorija - Opština Kanjiža.

Mander, J. i Goldsmith, E. (2003). Globalizacija argumenti protiv. Beograd, Republika Srbija: CLIO.

Mirecki, N. Wehinger, T. i Jaklič, M. (Ur.). (2011). Priručnik za organsku proizvodnju za poljoprivredne proizvođače. Podgorica, Crna Gora: Biotehnički fakultet Podgorica.

Ministarstvo za nauku i tehnološki razvoj. (2009). Održivi razvoj Srbije: Naša zajednička budućnost. Beograd, Republika Srbija.

Mreža za podršku ruralnom razvoju. (2015). Nacionalni program ruralnog razvoja. www.ruralinfoserbia.rs, str. 16

Pečujlić, M. (2002). Globalizacija: dva lika sveta. Beograd, Republika Srbija: Beogradska otvorena škola.

Radić, J. (2007). Ekonomija rada i socijalna politika Evropske unije. Subotica, Republika Srbija: Ekonomski fakultet.

Reinert, E. S. (2004). Globalna ekonomija: Kako su bogati postali bogati i zašto siromašni postaju siromašniji. Beograd, Republika Srbija: Čigoja štampa.

Ristic, L. (2013). Strategic management of sustainable rural development in the Republic of Serbia. Economic Horizons, 15(3), 233-248, doi: 10.5937/ekonhor1303229R.

Serbia organica. (2013). Oraganska poljopriveda. www. serbiaorganica.

Stendidž, T. (2009). Jestiva istorija čovečanstva. Beograd, Republika Srbija: Geopoetika.

Vlada Republike Srbije. (2003). Strategija za smanjenje siromaštva u Srbiji. www.srbija.gov.rs, str. 114, 147.

Vlada Republike Srbije. (2014). Drugi nacionalni izveštaj o socijalnom ukuljučivanju i smanjenju siromaštva u Srbiji. www. ljudskaprava.gov.rs

Primljeno 30. juna 2015, nakon dve revizije, prihvaćeno za publikovanje 17. avgusta 2015. Elektronska verzija objavljena 25. avgusta 2015.

Ljubica Komazec je redovni profesor na Ekonomskom fakultetu u Subotici Univerziteta u Novom Sadu, na kojem izvodi nastavu na svim nivoima studija, iz nastavnih predmeta Ekonomika preduzeća, Menadžment životnom sredinom, Ekološki urbani inženjering i Teorije troškova. Doktorirala je iz oblasti ekonomske efikasnosti, a veći broj radova je objavila iz održivog razvoja, ekološkog upravljanja i društvene odgovornosti kompanija.

Marko Aleksić je demonstrator na Ekonomskom fakultetu u Subotici Univerziteta u Novom Sadu, na nastavnim predmetima Menadžment $u$ agrobiznisu, Menadžment proizvodnje organske hrane, Menadžment životnom sredinom i Agrobiznis strategija. 


\title{
ORGANIC AGRICULTURAL PRODUCTION IN THE FUNCTION OF REDUCING RURAL POVERTY - THE EXAMPLE OF VELEBIT VILLAGE IN THE A.P. OF VOJVODINA
}

\author{
Ljubica Komazec*, Marko Aleksic \\ Faculty of Economics in Subotica - University of Novi Sad, Subotica, The Republic of Serbia
}

\begin{abstract}
Disturbing media pictures of the deterioration and disappearance of villages in almost all parts of the Republic of Serbia (RS), as a consequence of insufficient progress in the implementation of the paradigm of the rural way of life, desirable and necessary for any community and any economy, are an alarming call to every subject of the society to do whatever they are entitled to and capable of to stop these unfavorable processes. The potentials of a small rural community in RS to survive and develop for its own benefit and for the benefit of the society as a whole have studied in this article. Bearing in mind the fact that relevant social documents have their significance and role in all social processes, but are not a sufficient precondition for their improvement, the authors surveyed and interviewed the local population in the Velebit village about their attitudes, potentials, needs and limitations regarding the establishment of and their permanent involvement in organic agricultural production necessary for the village to survive and improve its economic and social position. The research results show that the inhabitants of the village of Velebit are interested in remaining in the countryside and setting up organic agricultural production, but they need assistance, both advisory and financial, as they lack sufficient capacities for it.
\end{abstract}

Keywords: organic production, poverty rate, rural environments, sustainable development

JEL Classification: Q01, Q18, Q58 